\title{
Central Banks' Monetary Policy in the Face of the COVID-19 Economic Crisis: Monetary Stimulus and the Emergence of CBDCs
}

\author{
Miguel Ángel Echarte Fernández *(i), Sergio Luis Náñez Alonso *(i), Javier Jorge-Vázquez (i) \\ and Ricardo Francisco Reier Forradellas (D)
}

Citation: Echarte Fernández, M.Á.; Náñez Alonso, S.L.; Jorge-Vázquez, J.; Reier Forradellas, R.F. Central Banks' Monetary Policy in the Face of the COVID-19 Economic Crisis:

Monetary Stimulus and the Emergence of CBDCs. Sustainability 2021, 13, 4242. https://doi.org/ $10.3390 /$ su13084242

Academic Editors: Philipp Bagus, Chunjiang An,

Antonio Sánchez-Bayón, Miguel A. Alonso Neira and José

Antonio Peña-Ramos

Received: 22 February 2021

Accepted: 9 April 2021

Published: 11 April 2021

Publisher's Note: MDPI stays neutral with regard to jurisdictional claims in published maps and institutional affiliations.

Copyright: (c) 2021 by the authors. Licensee MDPI, Basel, Switzerland. This article is an open access article distributed under the terms and conditions of the Creative Commons Attribution (CC BY) license (https:// creativecommons.org/licenses/by/ $4.0 /)$.
DEKIS Research Group, Department of Economics, Catholic University of Ávila, 05005 Avila, Spain; javier.jorge@ucavila.es (J.J.-V.); ricardo.reier@ucavila.es (R.F.R.F.)

* Correspondence: mangel.echarte@ucavila.es (M.Á.E.F.); sergio.nanez@ucavila.es (S.L.N.A.)

\begin{abstract}
This article analyzes the monetary policy of major central banks during the economic crisis generated by the COVID-19 pandemic. Rising public debt in many countries is being financed through asset purchases by monetary authorities. Although these stimulus policies predate the pandemic, they have been significantly boosted as many governments face large financing needs. We have been in a low interest rate environment for years and some governments have issued debt securities at negative rates. In addition, the rise of decentralized cryptocurrencies, based on blockchain technology, has created greater competition in the international monetary system and many governments have considered the creation of centralized virtual currencies, known as central bank digital currencies (CBDCs). We will analyze some relevant cases, with an emphasis on the digital euro project. The methodology is based on the analysis of the evolution of monetary variables. Pearson's correlation will be used to establish some relationships between them. There is a strong similarity in the expansionary monetary policies of central banks. Although the growth of the money supply has not been passed on to the CPI, it has been passed on to the financial markets and the price of assets such as Bitcoin or gold.
\end{abstract}

Keywords: expansionary monetary policy; CBDC; negative interest rates; monetary stimulus; digital currencies; international monetary systems; central banks; inflation; digitization; digital euro

\section{Introduction}

The monetary policy of central banks in recent years has been characterized by the credit facilities they have granted to governments through the purchase of government bonds [1]. In fact, this expansionary policy has been predominant since the beginning of the 21st century. After the dot.com crisis and the terrorist attack on the Twin Towers in New York, the Federal Reserve (Fed) and the European Central Bank (ECB) lowered interest rates to avoid a deep recession in a delicate political scenario. Low interest rates coincided with the creation of the euro and many macroeconomic imbalances were generated during the period 2002-2007 [2,3]. Many investment projects were financed without a real savings base, especially in the real estate sector, until the bubble came to an end when interest rates rose and oversupply in this sector became apparent. The reduction in interest rates, together with other credit facilities (lower collateral and access to finance requirements) was not due to an increase in savings going into investment but to the manipulation of one of the essential market signals which is the interest rate, i.e., the price of present goods concerning future goods [4,5]. The negative effects of artificially lowering interest rates were already studied by Ludwig von Mises who pointed out that " ... the drop in interest rates falsifies the businessman's calculation. Although the amount of capital goods available did not increase, the calculation employs figures which would be utilizable only if such an increase had taken place. The result of such calculations is therefore misleading. They make some projects appear 
profitable and realizable which a correct calculation, based on an interest rate not manipulated by credit expansion, would have shown as unrealizable. Entrepreneurs embark upon the execution of such projects. Business activities are stimulated. A boom begins" [6].

The outbreak of the crisis, known as the Great Recession, came with the bankruptcy of the investment bank Lehman Brothers in the United States (US). The government had already rescued other entities such as Fannie Mae, Freddie Mac, the insurance company AIG, and the investment bank Goldman Sachs, but it let Lehman fall so as not to encourage moral hazard [4]. Some authors [7,8] consider that the crisis was caused by financial deregulation, which allowed the securitization of mortgage assets and the appearance of highly sophisticated financial derivatives, although, in reality, the financial system is highly regulated and intervened (whether the regulation is adequate is a separate question) and at the same time highly privileged [9]. To deal with the crisis, central banks started a new phase of credit expansion through Quantitative Easing (QE) programs [10]. The Fed, the ECB, and the Bank of Japan (BOJ), with the Abenomics program, followed this path, which continues to this day [11]. Abenomics emerged at the end of 2012 and was named after Shinzo Abe, then prime minister of the country. This monetary expansion was accompanied by fiscal stimulus. The truth is that Japan has been applying these Keynesian policies for years without emerging from economic stagnation and is currently the country with the highest public debt as a percentage of GDP in the world [12]. In the case of China, the People's Bank of China (PBOC) continued its policy of currency devaluation to boost its exports.

In fact, the pandemic has further accelerated expansionary policies. These policies even led to the unconventional phenomenon of negative interest rates at which German government debt has been financed for years [13,14]. In December 2020, Spanish ten-year government bonds were also issued at negative interest rates, although this had previously been the case for bonds below that period. Negative rates are a subsidy to borrowing and a loss for creditors. In principle, they should encourage investment in the real economy, but this has not happened because the profitability of projects is very low due to overregulation and the tax burden. There is a saying in finance that "you can lead a horse to the river, but you cannot force it to drink" and it refers to the fact that, despite encouraging borrowing to finance projects, economic agents may not be interested in taking on debt either because they have memories of previous crises where such policies were encouraged or because they cannot find profitable investment projects in the market. The interest of some central banks in ensuring that credit and liquidity flow to the private business sector is so great that, for example, for years the ECB has been penalizing commercial banks for making deposits on its accounts at $0.5 \%$. The aim is for banks to use these resources to lend to economic agents.

It is true that expansionary policies, by increasing the money supply, usually lead to inflation. However, this does not seem to have happened if we look at the evolution of the Consumer Price Index (CPI) in the US and the euro area. In August 2020, the Fed, chaired by Jerome Powell, announced a new monetary easing allowing inflation to be above $2 \%$ to encourage investment and employment, which has been hard hit by the pandemic. The target for CPI not to exceed $2 \%$ will no longer be annual and will be sought to be achieved over an average number of years. At the end of September 2020, Christine Lagarde acknowledged at a conference in Frankfurt that the ECB also intends to change its target for inflation, as measured by the harmonized CPI, not to exceed $2 \%$ per year. It should be remembered that while the Fed has a dual objective-to foster economic growth and maintain price stability-which may be contradictory in the long run, the ECB's objective is solely to achieve price stability. Although inflation is no longer a problem in developed countries, there are countries with high inflation rates in Latin America (Venezuela has the highest inflation in the world and Argentina has double-digit inflation rates) and some poor countries in Africa.

However, it should be noted that the CPI does not reflect the price of real estate or financial assets [15]. Credit has not flowed strongly to investment projects in the real 
economy, but has been directed to financial equity markets, especially sovereign bonds. In addition, there has been, in parallel, an increase in demand for liquid assets such as government currencies (euro, dollar, etc.) and for assets considered as low risk such as government bonds of solvent countries. This means that the great monetary expansion of the last few years has not been reflected in an increase in the prices of consumer goods but may be generating a new bubble in fixed income [16].

In the aftermath of the 2008 international financial crisis, a new digital asset based on blockchain technology emerged. This was Bitcoin, a private, decentralized cryptocurrency. Over the years, many such cryptocurrencies have emerged (Ripple, Ethereum, Litecoin, etc.). These virtual currencies are intangible real assets. The main advantage of these currencies is that their value is independent of political decisions as they are not regulated by governments or controlled by any central bank. They have not yet established themselves as a generally accepted means of payment and their demand is based on the expectation of price increases. However, this may change in the coming years. In fact, in February 2021, the city council of Miami (USA) approved that its citizens pay part of their taxes in Bitcoin and that public employees receive part of their salaries in this cryptocurrency. In the case of Bitcoin, the supply is determined at 21 million units, so it is expected to be an asset that does not lose value in the long term (deflationary asset), although at the moment, it is highly unstable, as shown in Figure 1.

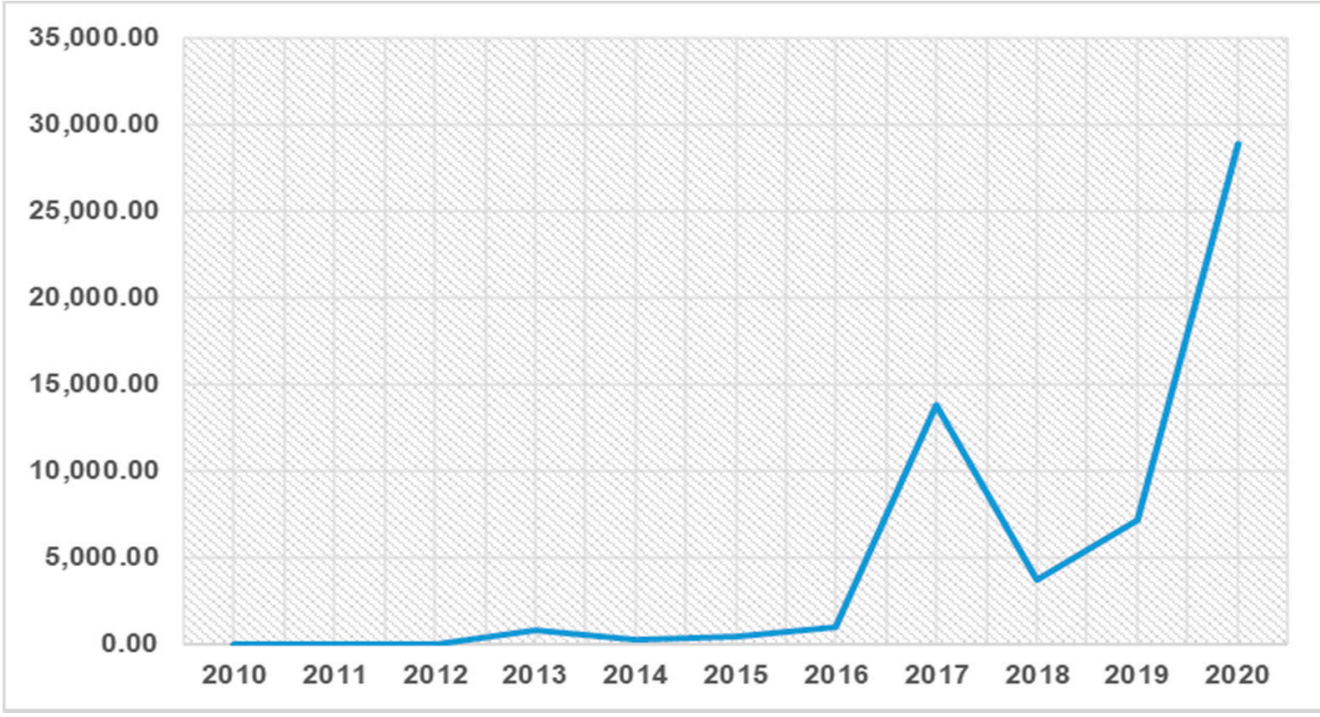

Figure 1. Bitcoin price evolution in dollars (2010-2020). The data correspond to the end of December of each year. Own elaboration, data from www.investing.com (accessed on 22 January 2021).

The price increase in the last period can be explained by the lack of confidence in fiat currencies and the significant investments made by some companies. For example, in February 2021 Tesla bought $\$ 1.5$ billion in Bitcoins.

Some authors [17-20] consider that competition from virtual currencies is similar to the proposal put forward by Friedrich Hayek in the late 1970s in which private banks issued banknotes competitively in the absence of a central bank and compulsory tender laws [21]. The high energy cost of mining has been identified as a drawback of cryptocurrencies. According to Statista data, the creation of new Bitcoin units requires more electricity consumption than is used in countries such as Switzerland, Israel, or Ireland. One study [22] shows that, by the end of 2019, Bitcoin's electricity consumption worldwide would be close to 50 Thw per year.

Some authors [23] argue that the transition of the monetary system to cryptocurrencies would result in an unacceptable amount of energy consumed in mining. However, other studies [24] point out that new energy sources can help achieve sustainability in cryptocurrency mining, in the context of making cities more sustainable. 
This criticism is similar to that made by authors such as John M. Keynes and Paul Samuelson of the classical gold standard. According to Samuelson: "It is absurd to waste resources digging gold out of the bowels of the earth, only to inter it back again in the vaults of Fort Knox" [25]. However, Roger Garrison has pointed out that these calculations must take into account the opportunity cost of employing a fiduciary system that induces recurrent boom and bust crises [26]. In reality, artificial monetary expansion processes create strains on natural resources by causing raw materials to be used in projects that would not normally be profitable. An example would be the huge amount of resources that were unnecessarily shifted to housing construction during the housing bubble between 2002 and 2007 [27].

The success of these cryptocurrencies and Facebook's announcement to create a decentralized virtual currency more stable than other cryptocurrencies (stablecoin), as it is backed by a basket of currencies, has led many central banks to study the creation of a centralized cryptocurrency, using blockchain technology, or a virtual currency issued by the central bank, known as CBDCs (Central Bank Digital Currencies) [28-36]. These projects will be discussed in more detail below.

In recent years, the emergence of digital means of payment has led to a reduction in the use of cash in economic transactions in developed countries such as Sweden and the Netherlands. As Nikola Fabris points out, "Sweden heads the vanguard. According to the Riksbank, the Swedish central bank (2018), at the last count only 13\% of Sweden's payments were made using cash, compared with a European average of nearly $80 \%$ " [37].

Something similar happens in China where citizens use mobile applications such as WeChat or Alipay to make purchases. Although in many countries this preference has emerged spontaneously, many governments are trying to restrict cash transactions. In the case of Spain, there is a draft law to ban cash payments above 1000 euros. At the moment, the limit is $€ 2500$. Phasing out cash may be a way for commercial banks to charge negative interest on their depositors' bank accounts without running the risk of deposit withdrawals. In this way, they would recover part of the profitability they are losing in a low interest rate scenario, although at the cost of harming depositors and increasing financial repression [1]. If there were a cash coefficient of $100 \%$ for demand deposits, it would make sense for the depositor to pay the bank an amount for the work of guarding or custody of the money, but we are not in this system [4].

This trend has been exacerbated by the pandemic because, although the World Health Organization (WHO) has denied that it is a source of the spread of the virus, it has recommended the use of electronic means of payment. Cash has the advantage of preserving the anonymity of transactions and the economic freedom of agents. Proponents of phasing out cash argue that this would reduce illegal transactions and money laundering because they believe they are often conducted in cash or through unregulated virtual currencies such as Bitcoin. However, the main conduit for these operations is in the banking system itself, particularly in offshore financial centers. In September 2020, a leak of documents from the US Treasury Department's Financial Crimes Enforcement Network (FinCen Files) implicated large commercial banks in money laundering. The banks implicated include JP Morgan and Deutsche Bank.

Before the emergence of COVID-19, there were signs that major world economies were in a slowdown or stagnation, if not recession. In the US, there was an inversion in the yield curve of sovereign debt securities and PMI (Purchasing Management Index) indicators were contracting. The yield curve is the relationship between the yield on a fixed income security and the time to maturity. Typically, the yield curve is positively sloped because short-term interest rates are usually lower than long-term interest rates [38,39]. When inverted, shortterm rates exceed long-term rates, showing that there are liquidity pressures in the market. The causes of this situation were multiple, but the trade war between the US and China, the Brexit phenomenon, which generated a lot of trade uncertainty, and the absence of structural reforms in many countries are worth highlighting.

This article aims to analyze the monetary policy of different central banks in the context of the COVID-19 pandemic and to show some implications of CBDCs. It will show 
that central banks have continued and increased monetary stimulus policies that were already in place before the global health crisis. In this context, there are a series of problems such as the risk of over-indebtedness, the monetary imbalances generated by the expansive monetary policy, or the problem of bank profitability in the face of low interest rates. The main contribution of the research is to analyze the effects of expansionary monetary policies before and during the pandemic by identifying long-term risks to the global economy. The following assumption will be made:

Hypothesis 1. Although the increase in liquidity has not been passed on to the prices of consumer goods and services (CPI) for the time being, it has been passed on to the financial markets and, especially, to public debt and to the price of certain assets that can fulfil a monetary function, such as gold and Bitcoin.

A limitation of this study is that little time has passed since the pandemic emerged and that it is still going on. However, it is argued that the expansionary trend predates this health crisis so that monetary policies before COVID-19 can be studied, and some conclusions are drawn.

\section{Materials and Methods}

The data used come from primary sources (calculations prepared by central banks and international economic organizations such as the IMF) or from secondary sources that are referenced in the figures. All graphics were produced by the authors and show the evolution of different macroeconomic variables (interest rates, monetary issuance, public debt, etc.) during the period 2010-2020. This period was chosen because it allows us to compare the response of central banks to the latest economic crises, one of monetary origin (the Great Recession of 2008) and the other generated by an external shock (the COVID-19 crisis). It is a long period that allows important conclusions to be drawn. The study focuses on three currency areas (US, Eurozone, and Japan). The analysis of the effects of monetary policy is based on the contributions of different authors, among them those of the Austrian school of economics (Ludwig von Mises, Friedrich Hayek, Huerta de Soto, etc.). The Austrian theory of the business cycle considers that the processes of artificial credit expansion generate a generalized malinvestment that ultimately ends in an economic crisis. There are other opposing approaches, such as those of Keynesian theorists or monetarists. The Keynesian approach emphasizes the short run, and the monetarists consider that monetary policy does not generate real effects on the production structure in the long run. We reviewed the academic literature on centralized virtual currencies and also the most recent articles and reports on monetary policy during the pandemic. Although there are not many references on this issue, we can highlight a few of them. [40-44]. To fulfill the scientific objectives formulated and proceed to contrast the research hypothesis, we applied the empirical analytical method, through the analysis of frequencies and correlations. A Pearson correlation was used to relate different variables with the SPSS program. Table A1 in the Appendix A shows the descriptive statistics used in the study and subsequent Pearson correlation analysis. The data in the table confirm the analysis. There has been significant growth in the monetary aggregate M3 in the euro area, especially since the arrival of the pandemic, but this has not translated into an increase in the CPI. In fact, the year ended in deflation, although in the first months of 2021, there was a slight upturn in inflation. However, the increase in M3 does explain the higher market capitalization of the selected indices, the growth of public debt in many countries, and the rise in the price of Bitcoin and gold. In the case of Europe, data from Germany and Spain are shown because they represent two opposing examples of economic policy. Germany has had a surplus in its public accounts and its debt has grown modestly, while Spain has been running a fiscal deficit and increasing its indebtedness for years. As for Japan, the increase in M2, especially since 2020, has not been reflected in the prices of goods and services. However, this growth has had an impact on the increase in the stock of public debt. On the other hand, in the US, the expansion of the Fed's balance sheet has not been passed on to the 
CPI either, but it has been passed on to financial markets. [45]. The Dow Jones index was chosen because it represents the 30 most important industrial companies in the country.

Regarding the correlation test that was performed and that we mentioned earlier, it is Pearson's correlation coefficient. This is a test that measures the statistical relationship between two continuous variables. The correlation coefficient can take a range of values from +1 to -1 . A value of 0 indicates that there is no association between the two variables. A value greater than 0 indicates a positive association [46-48]. That is, as the value of one variable increases, so does the value of the other. A value less than 0 indicates a negative association; that is, as the value of one variable increases, the value of the other decreases.

In our study, we carried out the analysis employing Pearson's correlation because our variables fulfilled the following: 1 . The measurement scale is an interval or ratio scale. 2. The variables are distributed in an approximate way [48]. The association is linear; and 3. There are no outliers in the data [47]. All this, through Equation (1):

$$
r=\frac{\sum x y}{\sqrt{\left(\sum x^{2}\right)\left(\sum y^{2}\right)}}
$$

where $r$ = Product-moment coefficient of linear correlation. We have used Pearson's correlation coefficient because for our analysis, it has two advantages: The value is independent of whatever unit is used to measure the variables, and if the sample is large, it generates high estimation accuracy $[47,48]$.

\section{Results}

3.1. Interest Rate and Central Bank Balance Sheet Developments before the COVID-19 Pandemic

Figure 2 shows a significant reduction in rates after the Great Recession. In the case of the ECB, the benchmark interest rate has been $0 \%$ since 2016 but the Fed has them at $0.25 \%$ and the $\mathrm{BOJ}$ at $-0.1 \%$ since 2017. It is natural for central banks to follow similar policies because in a world with free movement of capital, money would tend to go to those areas where interest rates are higher, leaving areas with low interest rates.

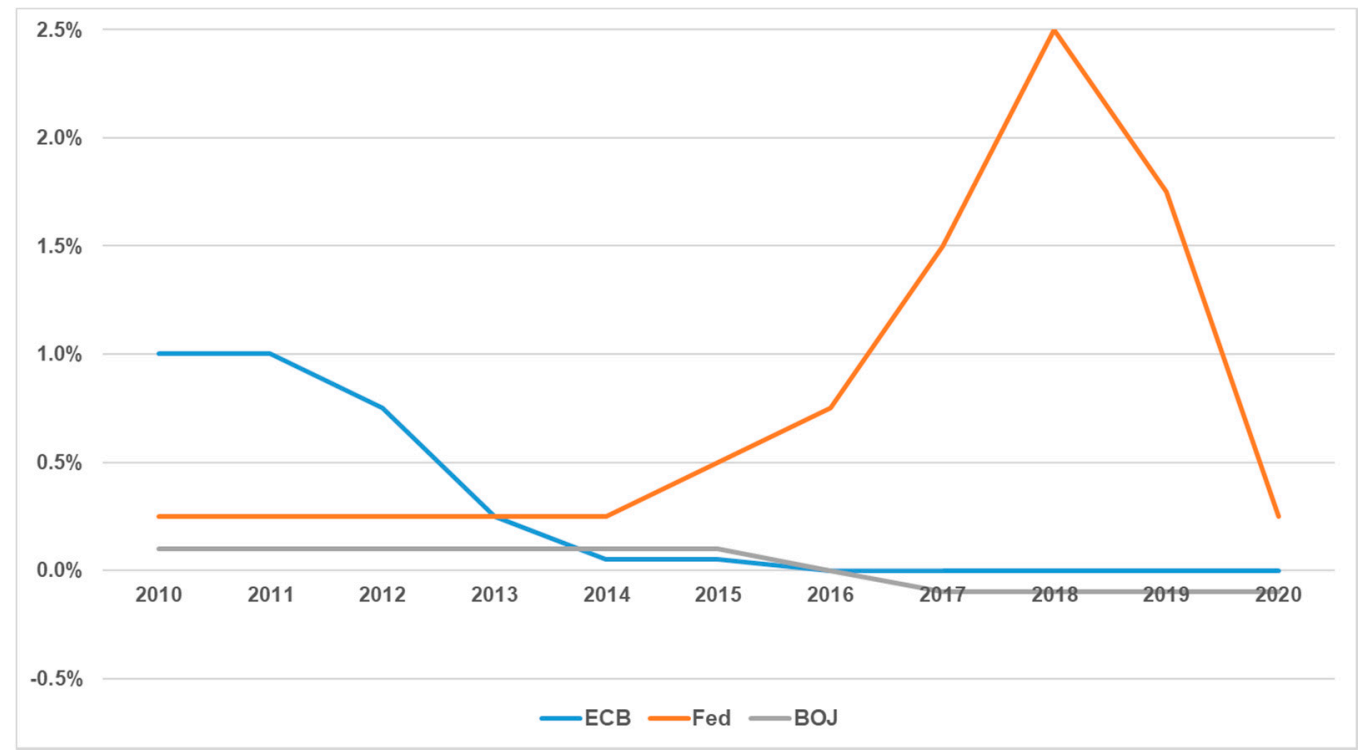

Figure 2. Interest rate developments in different currency areas. Source: Own elaboration based on data from ECB, Federal Reserve, and BOJ. 
Figures 3 and 4 show the composition of the ECB's balance sheet, separating assets from liabilities. On the assets side, the large growth in government bonds issued by the various euro area governments can be seen. On the liabilities side of the ECB's balance sheet, bonds to euro area credit institutions and banknotes in circulation stand out. It can be seen that liabilities to financial institutions have increased despite the ECB's penalties on bank deposits.

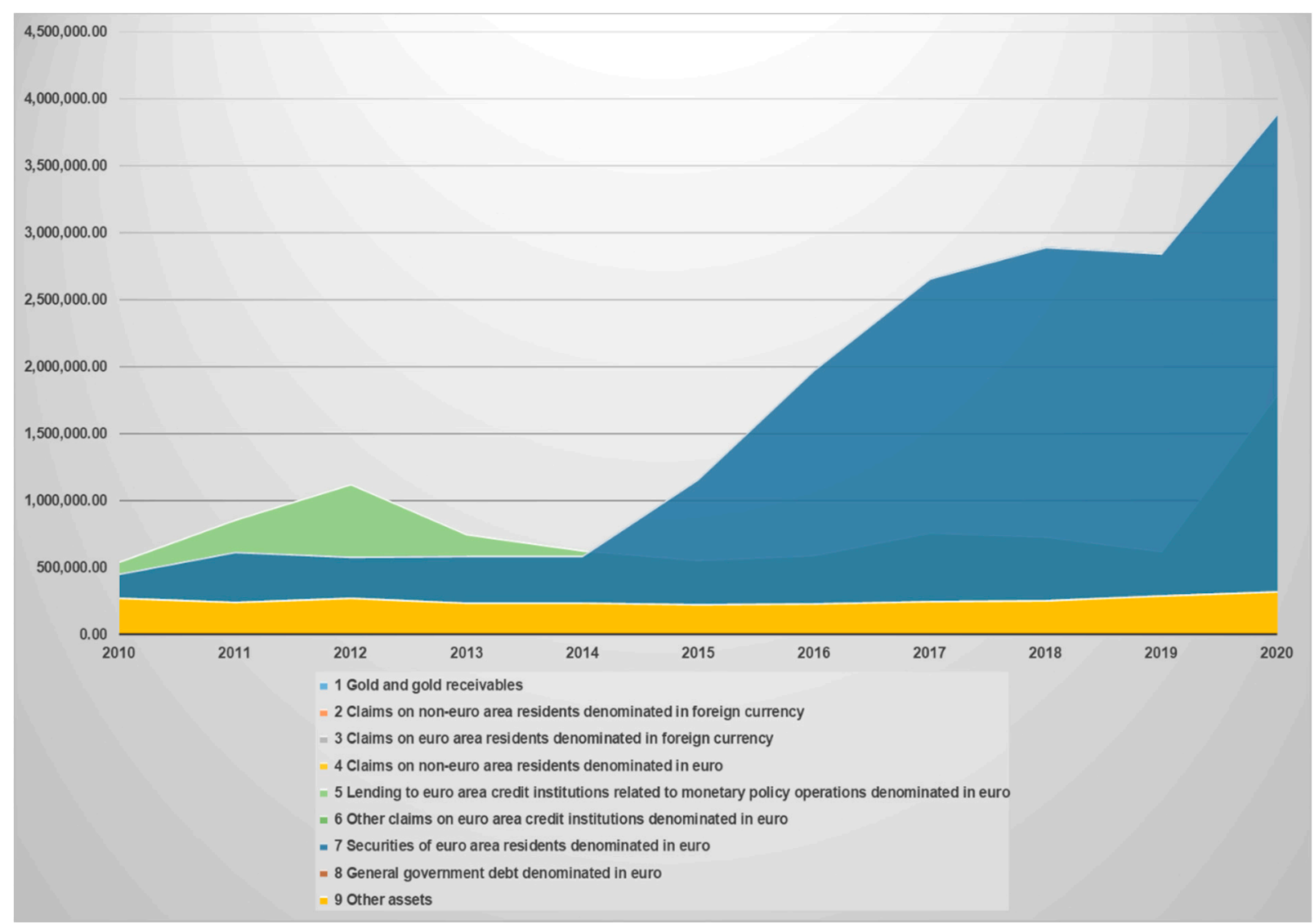

Figure 3. Changes in the ECB's assets (in EUR million) over the period 2010-2020. The annual consolidated balance sheet of the Eurosystem. Source: Own elaboration based on data from ECB.

In the case of the Fed, Figure 5 shows an increase in assets in the post-Great Recession period [49], a balance sheet reduction starting in 2017 and running through the summer of 2019, and from September 2019, the Fed's balance sheet expands again, before the COVID-19 crisis. The Fed injected a large amount of liquidity to support banks in the face of a liquidity crisis in the repo market. Repos have repurchased agreements on securities (usually government bonds, treasury bills, bonds, or debentures) that commercial banks enter into to obtain short-term funding. The purchase of securities has been boosted during the pandemic. 


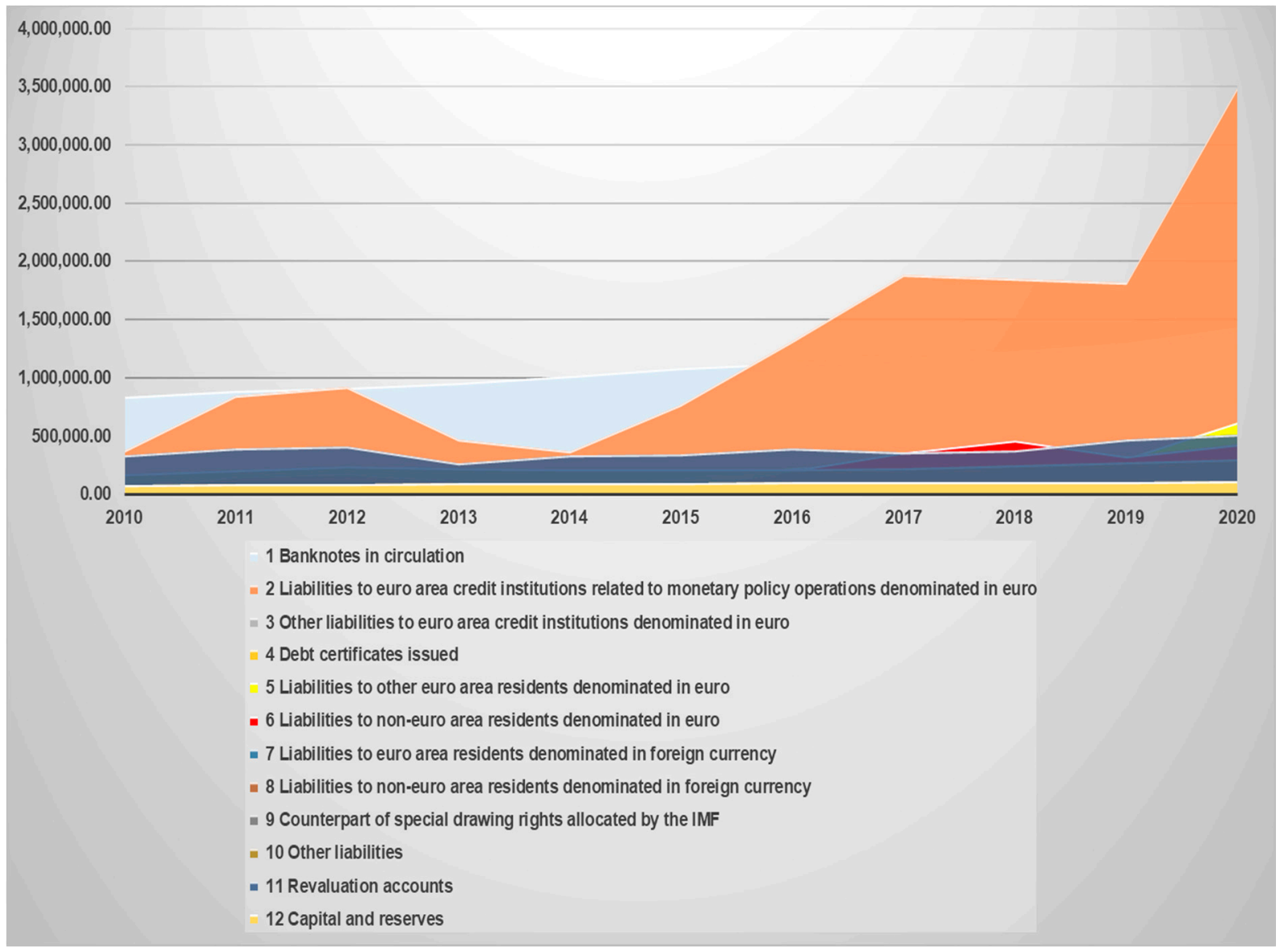

Figure 4. Changes in the ECB's liabilities (in EUR million) over the period 2010-2019. The annual consolidated balance sheet of the Eurosystem. Source: Own elaboration based on data from ECB.

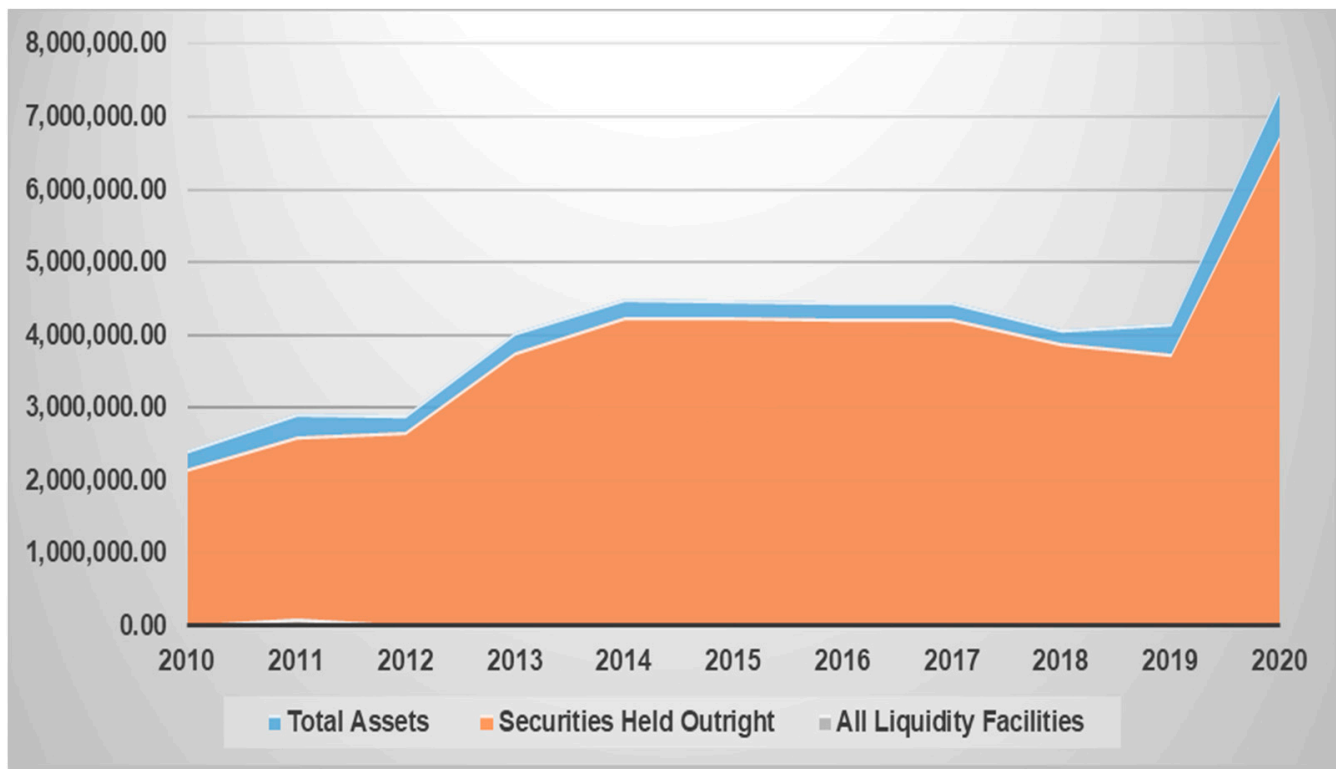

Figure 5. Total assets and selection of components of the Fed's balance sheet (in millions of dollars) over the period 2010-2020. Source: Own elaboration based on data from the Federal Reserve.

The increase in liquidity (coins and banknotes in circulation) during 2020 can be seen in Figure 6. Similarly, there is a significant increase in financial institutions' deposits. 


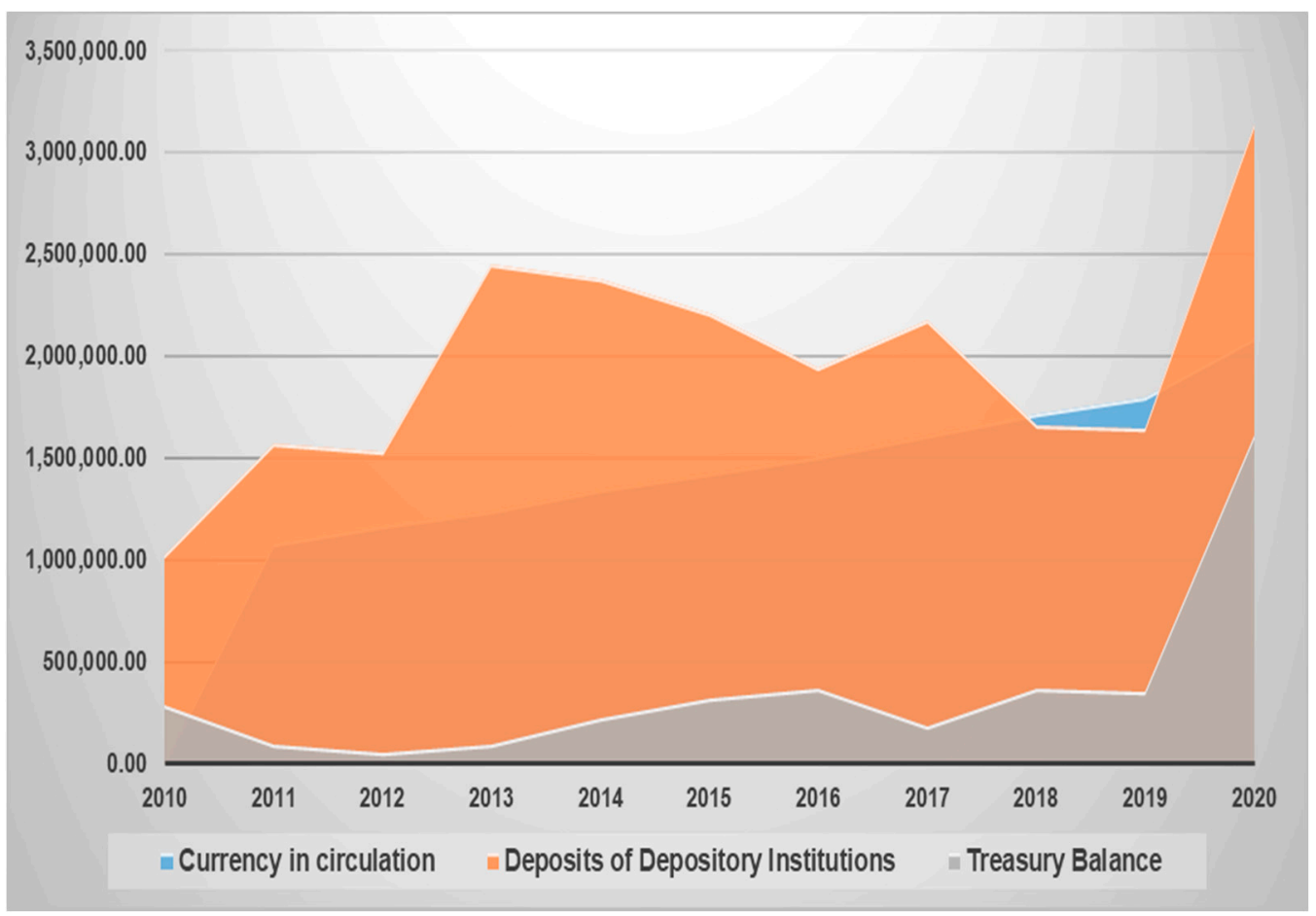

Figure 6. Selected liabilities of the Federal Reserve (in millions of dollars) over the period 2010-2020. Source: Own elaboration based on data from the Federal Reserve.

Figure 7 shows a strong positive correlation between $\mathrm{M} 3$ in the euro area and the price of Bitcoin. The same is true if we compare M2 in Japan with this cryptocurrency. This positive correlation also occurs concerning the price of gold, as shown in Figure 8.

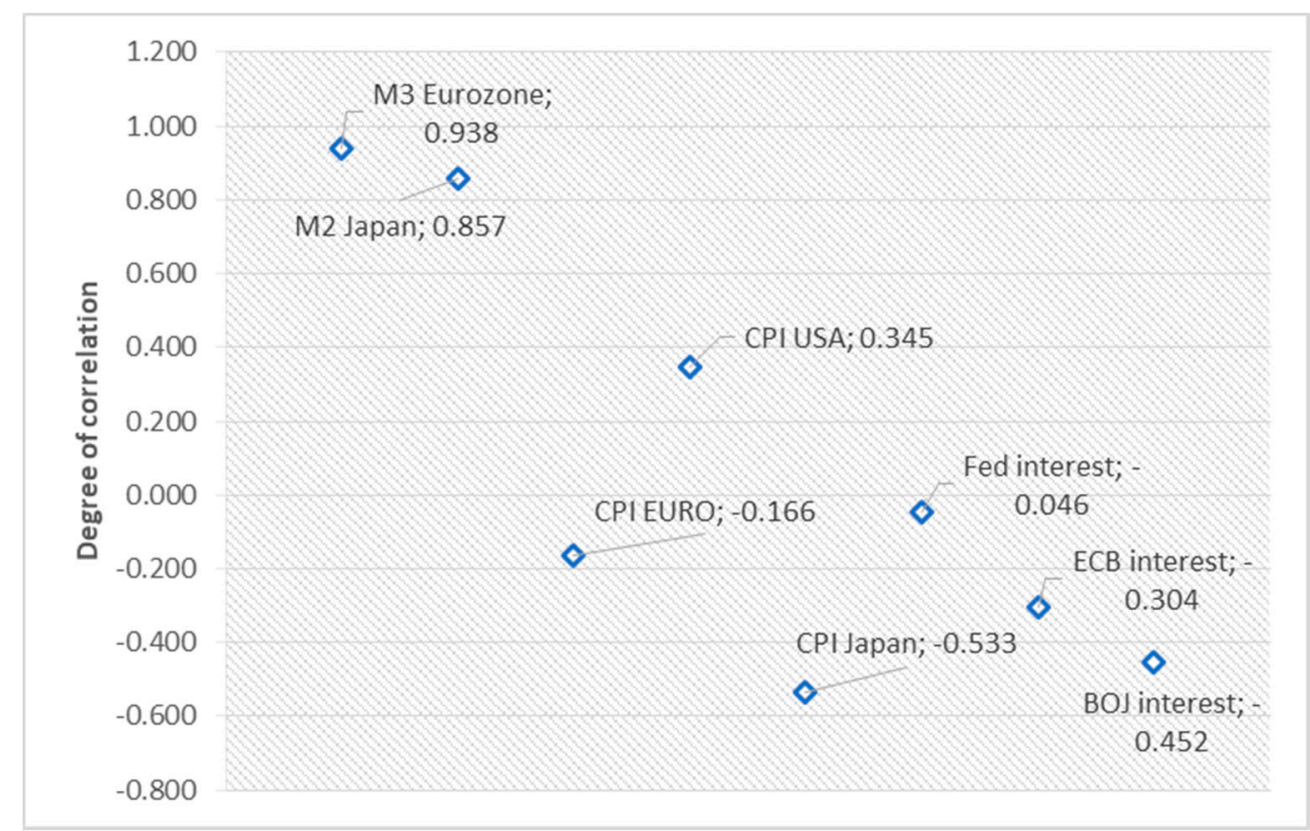

Figure 7. Pearson's correlation, BTC \$ price with variables. Source: Own elaboration. 


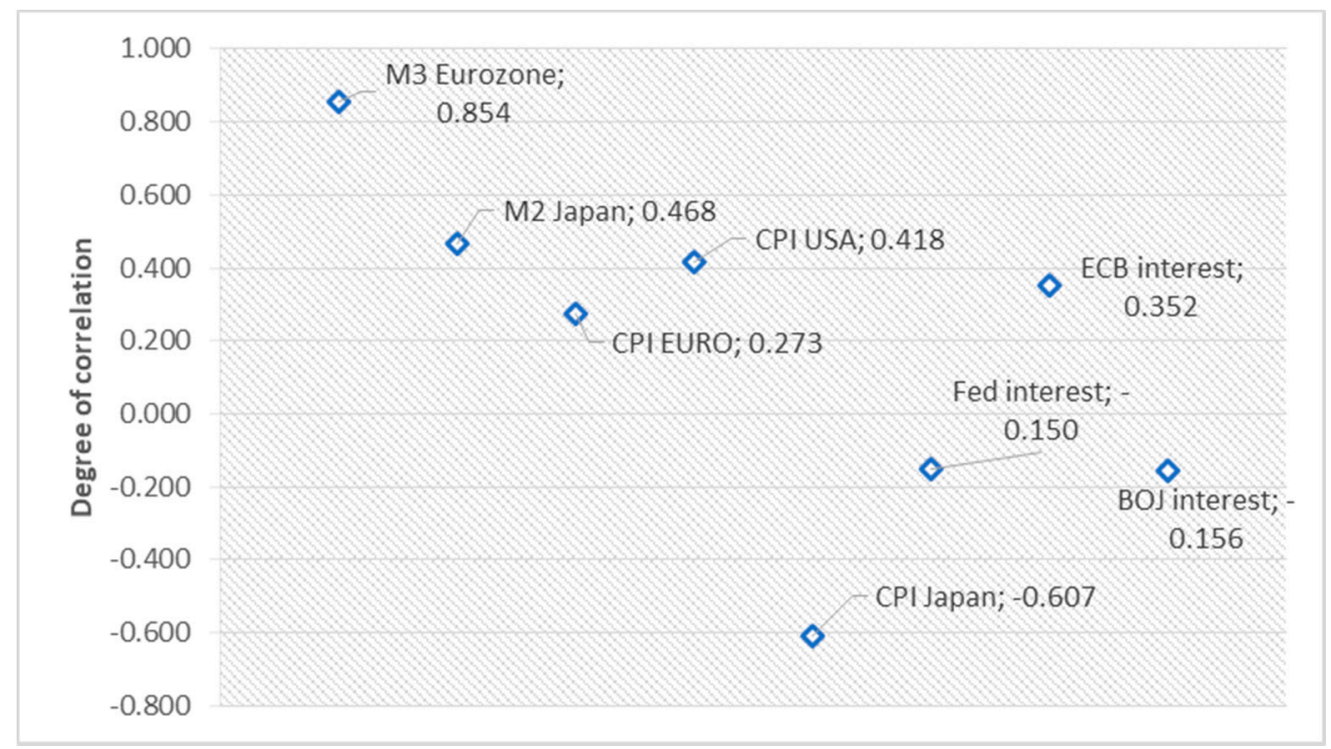

Figure 8. Pearson's correlation, gold futures with variables. Source: Own elaboration.

\subsection{The Economic Effects of the COVID-19 Health Crisis and the Reactions of Central Banks}

The COVID-19 pandemic originated in late 2019 in the city of Wuhan (Hubei-China) and later spread to Europe and other continents. Governments reacted by enacting population containment measures (except for Sweden) and mobility restrictions. The health crisis is causing the death of many people, putting countries' health systems in great difficulty. This health crisis has been transferred to the real economy as the paralysis of many productive activities (except for those that can be carried out by teleworking or basic services) and the drastic reduction in demand for certain goods and services have generated a scenario of great economic uncertainty. There was, therefore, a simultaneous contraction of supply and demand.

At the beginning of the health crisis, financial markets suffered from the fall in the share price of many companies, although they subsequently recovered, mainly due to the liquidity creation policies of central banks. In the oil futures market, a barrel of oil was trading at negative prices in April as an oversupply of crude oil was being generated in an environment of reduced demand for land and air transport.

Initially, the countries most affected by COVID-19 in Europe were Italy (the first cases occurred in the north of the country) and Spain. They were also the countries with the highest stock of public debt to GDP. In the case of Italy, the public debt/GDP ratio was $133 \%$ and in Spain $96 \%$.

Figure 9 shows how Spanish public debt, unlike that of Germany or the Netherlands, grew from 2012 onwards. In that year, Spain came close to bankruptcy when the risk premium reached peak levels, ending the year with the highest public deficit in the European Union (EU), above 10\% [1]. Serious doubts were raised in the markets about staying in the euro, but Mario Draghi's decision to do everything possible to maintain the common currency ("Whatever it takes") dispelled doubts about the short-term recovery of the Spanish economy, which also benefited from the fall in oil prices from 2014 and some internal reforms, such as the labor market. There was some recovery from the crisis, accumulating years of economic growth. However, in 2019, there were signs of a slowdown until the economy suffered the impact of the pandemic. 


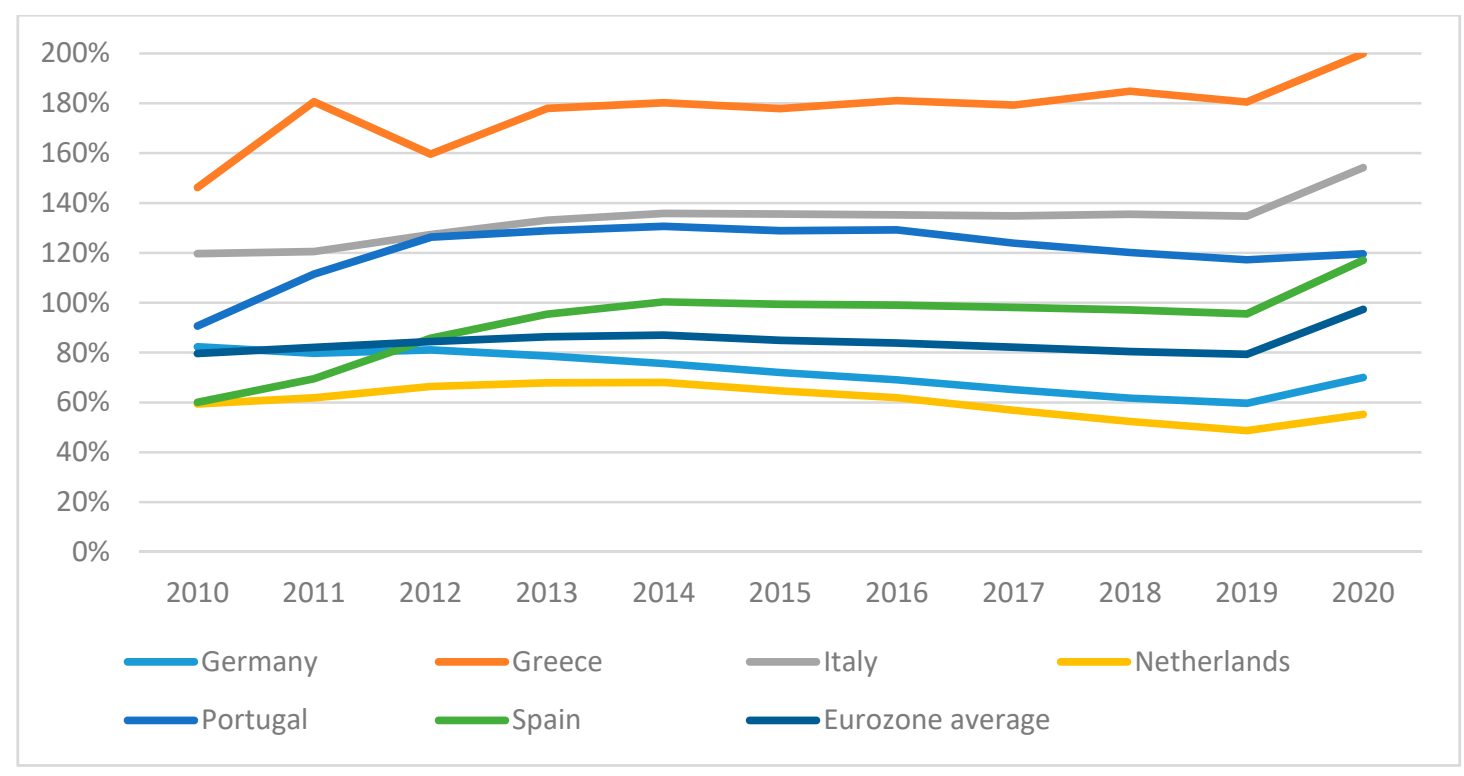

Figure 9. Evolution of the stock of public debt/GDP, as a percentage, in different countries (2008-2018). Source: Own elaboration based on data from IMF.

Spain entered a recession in the second quarter of 2020, when, according to data from the National Statistics Institute (INE), quarterly GDP fell by $17.8 \%$. This is the quarter-onquarter rate (compared with the previous quarter). In year-on-year terms (comparing with the same quarter of the previous year), GDP fell by $21.5 \%$. This was the largest contraction since the beginning of the historical series in 1970. In the third quarter, Spain came out of recession due to the revival of economic activity during the summer months. However, annual GDP in 2020 fell by $11 \%$ compared to the previous year. This historic contraction was due to the paralysis of activity as a result of the house arrest decreed in mid-March that lasted until June. Interest rates on Spanish and Italian sovereign debt began to rise until 18 March 2020, when the ECB announced a new program to purchase 750 billion euros worth of securities. This program was announced by the Governing Council and is known as the Emergency Pandemic Purchase Program (EPPP). It is a temporary asset purchase program of private and public sector securities that seeks to counter risks to the monetary policy transmission mechanism and the euro area's outlook for the coronavirus. [50]. Along with this asset purchase program, the ECB improved the bank financing programs (Targeted Longer-Term Refinancing Operations-TLTRO—and Long-Term Refinancing Operation, or LTRO) that it had set up after the Great Recession, within the framework of unconventional policies, and in April, it created a new mechanism called Pandemic Emergency Longer-Term Refinancing Operations (PELTRO).

This has meant that the risk premiums of these countries have not soared, and they have been able to finance their debt at a lower cost. If these countries were not in the Eurozone and tried to monetize their fiscal deficits with issues by their central banks, their local currencies (the peseta or the lira) would depreciate on the international markets. In the case of the euro, the presence of countries with balanced accounts, such as Germany, generates greater confidence in the common currency.

In this way, the ECB, which since November 2019 has been under the presidency of Christine Lagarde, continued with the policies it had been developing since 2012 during Draghi's presidency. The ECB not only buys sovereign debt securities through Open Market Operations, but also corporate bonds on the secondary market. Thus, it coincides with the Fed's purchase policy, although it has not gone to the extreme, as the BOJ is doing, of buying shares in the markets. In fact, the BOJ is, as of December 2020, the largest owner of equities in the country [51].

These stimuli generate a great distortion of risk in these markets because it is more difficult for an individual investor or a collective investment institution (investment fund) 
to know whether the demand for these securities is based on solid fundamentals (solvency of the issuer) or on monetary policies to support certain companies, without discriminating between profitable companies and others that are not profitable but survive thanks to this permanent financing from the central banks.

The crisis generated by the pandemic in the EU countries, with the increase in fiscal deficits and public debt of their governments, led to the consideration of cooperation mechanisms at the supranational level. One of the most talked-about mechanisms was the issuance of corona-bonds, which consists of mutualizing the debt of EU countries. This was not the first time that this instrument was mentioned, since after the 2008 crisis some governments proposed it, under the name of Eurobonds. In 2020, this proposal was rejected by Germany, the Netherlands, Austria, and Finland. They had reasons to do so, as many southern European countries had structural public deficits and high levels of debt, even though a long time had passed since the Great Recession and years of economic growth.

In the end, a bailout program was approved which, although formally not the same as corona-bonds, is similar in practice as it relies on the economic capacity of certain countries that have had budgetary stability in recent years (frugal countries). In July 2020, this historic agreement was reached whereby the European Commission would borrow to finance a 750-billion-euro economic recovery program (Recovery Fund) in the form of grants and credits with certain conditionality.

These measures complement the ECB's asset purchase programs and are pushing the public debt of European countries to very high levels. In this context, in November 2020, Riccardo Fraccaro, an advisor to the Italian government, asked the ECB to cancel the debt issued during the pandemic. A manifesto headed by the economist Thomas Piketty was published some months later in the same vein, and some representatives of the Spanish government joined in. This proposal was rejected by the ECB, but if it is carried out at some point, it could lead to the ECB's insolvency and provoke a depreciation of the euro and a scenario of high inflation $[52,53]$.

To the EU, measures must be added to the aid granted by national governments, ranging from the granting of guarantees for bank loans, tax reductions or their deferral, liquidity injections, the assumption of payrolls through different mechanisms (in the case of Spain, through the "Expedientes de Regulación Temporal de Empleo" (ERTES)), etc. Evidently, these measures and others related to automatic stabilizers (unemployment benefits) have boosted public spending and the need to issue debt, as we have seen above [54].

The US opted for liquidity injections to households and firms. Some authors [44] have likened these policies to the famous "Friedman helicopter", analyzing how they could be applied in other regions. The idea of the helicopter comes from the contributions made by David Hume, who argued that the mere equitable distribution of newly created money, although it does not generate an unfair distribution of income, has no real effect on the economy [4].

In recent years, a heterodox current has emerged which argues that public deficits and debt are not a problem for a country with monetary autonomy because having a fiat currency issued by its central bank means that public spending can be financed in an unlimited way without creating adverse consequences. This theory considers that states cannot have solvency problems and that there are no budgetary constraints. The main representatives of this theory, known as Modern Monetary Theory or MMT, are Randall Wray and Warren Mosler, and it is growing in the US, where it emerged a few decades ago [55-57].

However, the truth is that public debt will have to be repaid in the future and this can be done in orthodox or heterodox ways. The former can be used to promote economic growth and achieve primary surpluses, while the latter can be used to restructure the debt or generate inflation. Although austerity in public spending is often seen as detrimental to economic expansion and growth, some authors point out that it can promote growth in certain contexts [58]. 


\section{Discussion}

One of the sectors where the biggest transformation is taking place is commercial or retail banking. The digitalization of finance means rethinking the number of branches and branch staff. In addition, low interest rates reduce the financial margins traditionally obtained by banks (the difference between the interest charged on loans, or asset transactions) and the interest paid on deposits (liability transactions). This makes many banks uncreditworthy. Some banks with an international presence can be profitable in other regions, but most banks depend on refinancing from the ECB. As a result of these factors, in the coming years the number of bank mergers may increase, and the sector will become more concentrated. In the case of Spain, the announcement of merger talks between Caixa Bank and Bankia was made at the beginning of September 2020, and these mergers will likely take place in other banks at the European level [59].

The international monetary system has undergone profound changes in the past and is likely to undergo further changes in the future. One of the best known of these was the Bretton Woods agreements signed in 1944 in New Hampshire (USA) by the Allied powers shortly before the end of World War II. Two international economic organizations (IEO), the World Bank and the International Monetary Fund (IMF), were created and a fixed exchange rate of 35 dollars per ounce of gold was established for transactions between central banks [60]. This monetary system, together with the trade opening promoted by the GATT (General Agreement on Tariffs and Trade), gave rise to a process of moderate globalization, as capital controls hindered financial globalization, which would begin in the 1990s [61]. During the decades after the war, central banks pursued an expansionary policy that aimed to reduce unemployment by accepting a rise in inflation. This trade-off between unemployment and inflation was based on the Phillips curve which, according to the evidence collected by this author for Britain and by Solow and Samuelson for the US, had a negative slope. This policy worked for a while, but in the 1970s, there was an economic crisis with high unemployment and inflation (stagflation) that challenged the negatively sloped Phillips curve and Keynesian theory [62]. This was the oil crisis generated by the decision of the Organization of Petroleum Exporting Countries (OPEC) to restrict the supply of barrels and by the depreciation of the dollar following the exit from the Bretton Woods system of fixed exchange rates. On 15 August 1971, President Richard Nixon unilaterally suspended the convertibility of the dollar and since then, the financial system has been based on unbacked fiat currencies. Although in the 1980s the Fed, under the chairmanship of Paul Volcker (1927-2019), tried to get out of stagflation by raising interest rates, imbalances were generated again, leading to the 1987 stock market crash [4].

This system is currently at a critical juncture because the world economy, which was already largely stagnant before the pandemic, has entered a phase of deep crisis. The increase in public debt is being financed with expansionary monetary policies that can be understood in the short term due to the impact of the pandemic, but which, if perpetuated, could aggravate the macroeconomic imbalances of the countries. Against this background, major changes in the monetary system are foreseeable. Some authors propose a return to the classical gold standard or some kind of real backing for fiat currencies $[4,63]$. On the other hand, others [61] propose a greater regulation of financial markets and even the limitation of financial flows with measures such as the Tobin tax.

The most popular proposal is to create centralized virtual currencies issued by the respective central banks. These currencies can, but need not, be based on a cryptographic system using blockchain technology. Several countries have considered this. We will briefly analyze the cases of Venezuela, Sweden, China, and the EU, but many central banks that are investigating it such as Israel, Iceland, Japan, and South Korea, among others. The first centralized cryptocurrency was created by Nicolás Maduro's regime in Venezuela at the end of 2017. It was the Petro and was backed by oil reserves and other commodities, but it has not generated trust because of the deep crisis in the country and the political regime behind it. The main objective behind the Petro was to circumvent international sanctions [64]. 
In Europe, the most interesting case is that of Sweden, as one of the reasons for creating a centralized virtual currency (e-krona) is the reduction in the demand for cash and the intention of the central bank, the Riksbank, to offer a digital alternative to private platforms such as Swish, which is very successful in the country. The case of China is very important as it is the first economic power to create a digital money, the electronic yuan, through the PBOC. However, China had a regulation banning Bitcoin initial coin offerings (ICOs) since 2017 [25]. There is currently a bill in India that aims to ban private cryptocurrencies while the creation of a centralized cryptocurrency is being considered.

The fact is that, as in Sweden, there is a growing trend towards the use of digital means of payment, and the central bank launched a series of tests in several cities in the country in May during the pandemic. The goal they have set is to have it widely used by 2022, when the Winter Olympics will take place. One of the intentions behind the virtual currency is to boost international demand for the yuan and to compete with the hegemony of the dollar in world trade [65]. This goal is very ambitious as the dollar is still the international reserve currency (the main foreign currency held by central banks) and most international trade transactions are done in this currency. Moreover, in many Latin American countries, economic agents try to save in dollars and the prices of many consumer durables are agreed in foreign currency. This is a process of spontaneous dollarization that occurs in countries such as Costa Rica, Peru, Colombia, and Argentina, among others. On the other hand, countries such as Ecuador, El Salvador, and Panama are officially dollarized [66-69]. The fact that the dollar is a highly demanded currency means that the Fed has more room for monetary expansion than other central banks whose currencies, although strong like the euro, do not have the same backing. In that sense, countries where demand for the local currency was already falling before the pandemic, such as Venezuela and Argentina, and have reacted with higher monetary issuance are facing galloping inflation [70]. However, this excessive inflation has been the dominant trend in South America, as shown by several studies [71,72].

The ECB is also considering the creation of a centralized virtual currency, the digital euro. In October 2020, they published a report analyzing the monetary policy implication of such a currency. In the document, they put forward different scenarios that could justify its creation: "A digital euro could be issued (i) to support the digitalization of the European economy and the strategic independence of the European Union; (ii) in response to a significant decline in the role of cash as a means of payment, (iii) if there is significant potential for foreign CBDCs or private digital payments to become widely used in the euro area, (iii) as a new monetary policy transmission channel, (iv) to mitigate risks to the normal provision of payment services, (v) to foster the international role of the euro, and (vi) to support improvements in the overall costs and ecological footprint of the monetary and payment systems" [73].

It is quite likely that several of these scenarios will occur in the coming years and that we will see a centralized virtual currency issued by the ECB. Regarding the last of these scenarios, it should be noted that CBDCs do not require mining, so the impact on the environment is residual compared to decentralized cryptocurrencies.

The report reflects the advantages of the possible creation of the digital euro and is similar to the argument made by other central banks: "In response to a decline in the use of cash, the Eurosystem could introduce a digital euro as an additional form of public money and means of payment. In order to satisfy the needs of users, the digital euro should be cheap to use (generating very low costs for users, like physical cash), secure (providing the highest levels of fraud prevention and offering consumer protection), risk-free (its holders should not be subject to any market risk or issuer default risk), easy to use (even for unskilled consumers and merchants) and efficient (permitting fast payments)" [73].

Although mention has been made of the trend in certain countries towards cash reduction, this is not happening in all European countries, and even less so in regions such as Latin America, where there is a strong informal economy. In Ecuador, during the presidency of Rafael Correa, an electronic money system was created, managed under a monopoly regime by the central bank, but it was not very successful due to mistrust in the 
system and the high demand for cash by economic agents. Cash (coins and banknotes) has the advantage of preserving the privacy of exchanges and of being more useful for a part of the population that does not use virtual platforms or electronic media. However, some authors argue that CBDCs can contribute to financial inclusion in rural areas [74].

One of the main reasons for creating these virtual currencies is to face competition from other means of payment that constrain the monetary policies of the ECB and other central banks. In turn, if the digital euro is demanded outside the euro area, the monetary policy of other central banks would be constrained. This possibility would give economic agents more monetary freedom, but would logically reduce the discretion of central banks. The phenomenon described above, if it were to occur, would be similar to the dollarization in Latin America discussed above.

Another interesting aspect of the report is that it analyzes the possibility of the digital euro helping to cope with an external shock such as the one we are experiencing with the COVID-19 pandemic. If economic agents consider that cash can more easily transmit contagion, demand for electronic means of payment may increase.

One of the most controversial aspects of the creation of CBDCs is the impact they could have on commercial banks in the event of a crisis of confidence and a banking panic. In such a scenario, economic agents could shift their deposits to the central bank's virtual currency, exacerbating the banks' financial problem. As the report points out: "In crisis situations, when savers have less confidence in the whole banking sector, liquid assets might be shifted very rapidly from commercial bank deposits to the digital euro if the operational obstacles to withdrawing money in the form of digital euro are lower than for withdrawing cash. This could increase the likelihood and severity of bank runs, weakening financial stability" [73].

A reduction of bank deposits into cash would reduce the impact of the bank multiplier operating in a fractional reserve system [4]. If the transfer of deposits is channeled to an account at the central bank (CBDC), the impact would also be reduced but to a lesser extent because the central bank would be able to finance projects through Open Market Operations. Even if there is a period of stability, CBDCs mean increased competition for commercial banks and render the deposit services they provide of little use. If banks wanted to keep their customers, they could raise the interest rates on their liability operations, but this would be very costly for these institutions in the current context. These facts, together with those mentioned above (low interest rates, digitalization of the sector), could put an end to the traditional banking model.

\section{Conclusions}

The current monetary policy of the main central banks (ECB, Fed, BOJ) is very expansionary as they are purchasing a significant part of the public debt issued by the respective governments. There is a strong similarity between the central banks' response to the Great Recession and their current reaction to the COVID-19 economic crisis. In the context of the pandemic, it is understandable that some stimulus is being encouraged to inject liquidity into a market that is suffering the consequences of the COVID-19 health and economic crisis. However, such policies are not the long-term solution, as they perpetuate imbalances and generate bubbles in financial markets that sooner or later end in a subsequent crisis of greater severity. Governments need to reform to balance public accounts and liberalize the economy so that the private sector can find sustainable investment projects that create jobs. Increased competition from decentralized virtual currencies coupled with the reduction of cash in certain countries is driving the creation of centralized virtual currencies by central banks. These currencies may have certain advantages (encouraging digitalization, lower environmental impact, etc.) but they have the disadvantage of removing the privacy of transactions and pose a risk to the traditional banking sector. The monetary stimulus policy is largely hiding the risk of many assets, which can generate long-term investment errors in the financial markets, and low interest rates are helping governments to finance their debt, but discourage savings and capital accumulation, while reducing the financial margin of banks and generating a poor allocation of resources that tend to be directed towards 
low value-added projects. In this scenario, questions of great importance for the world economy arise: Will the stimulus measures last long, what will happen when they end and interest rates rise, will there be a sovereign debt crisis, will inflation return to the European continent or to the US?

In this regard, in mid-February 2020, the Bundesbank warned of the risk of inflation (January CPI in Germany stood at 1.6\%) and of the advisability of raising interest rates even if it increases the financial cost for the most indebted governments. Central banks are at a crossroads: if expansionary policies end up generating inflation, they will have to raise interest rates, which would cause a sovereign debt crisis in many countries, but on the other hand, if they do not do so, there is a risk of a crisis with inflation (stagflation).

We have seen how the world economy was stagnating and some countries had entered into recession before the pandemic appeared, so we can conclude that a crisis was brewing, and COVID-19 was the definitive trigger. If expansionary policies continue for much longer, there is a risk of japanization of the EU leading to a deep stagnation of their respective economies. The US has a more dynamic market and, as we have pointed out, greater room for issuance, but it also has problems of fiscal deficit and debt which, if not corrected, could affect the international valuation of the dollar.

The data shown illustrate that the hypothesis is correct and that the expansionary monetary policy of central banks is being channeled into financial markets, allowing governments to finance themselves at low interest rates. Mistrust of fiat currencies is, moreover, one of the causes of the increase in the price of some cryptocurrencies and gold.

Author Contributions: Data Curation, M.Á.E.F. and S.L.N.A.; Formal Analysis, M.Á.E.F. and J.J.-V.; Investigation, M.Á.E.F.; Methodology, M.Á.E.F. and S.L.N.A. and J.J.-V.; Software, M.Á.E.F. and S.L.N.A.; Supervision: J.J.-V. and R.F.R.F.; Writing: M.Á.E.F.; Review \& editing, M.Á.E.F. All authors have read and agreed to the published version of the manuscript.

Funding: The APC was partially funded by the incentive granted to the authors by the Catholic University of Ávila.

Conflicts of Interest: The authors declare no conflict of interest.

\section{Appendix A}

Table A1. Descriptive statistics. Prepared by the author.

\begin{tabular}{|c|c|c|c|c|c|}
\hline & $\mathbf{N}$ & Minimum & Maximum & Media & Deviation \\
\hline Time & 19 & 01-FEB-12 & 01-FEB-21 & & \\
\hline M3 Eurozone & 11 & 0.04 & 0.12 & 0.06 & 0.03 \\
\hline CPI euro & 19 & -0.01 & 0.03 & 0.01 & 0.01 \\
\hline M.C (Dow Jones) & 1 & $25,916.00$ & $25,916.00$ & $25,916.00$ & \\
\hline M.C (Ibex-35) & 19 & 8073.70 & $11,178.30$ & 9248.22 & 873.31 \\
\hline M. C (DAX) & 19 & 6856.08 & $13,963.10$ & $10,891.31$ & 2037.44 \\
\hline Public Debt/GDP Spain & 18 & 0.72 & 1.17 & 0.97 & 0.09 \\
\hline Public Debt/GDP USA & 10 & 1.03 & 1.09 & 1.06 & 0.02 \\
\hline Public Debt/GDP Germany & 10 & 0.60 & 0.72 & 0.65 & 0.04 \\
\hline M2 Japan & 19 & 0.02 & 0.09 & 0.04 & 0.02 \\
\hline CPI USA & 19 & -0.01 & 0.00 & 0.00 & 0.00 \\
\hline Public Debt/GDP Japan & 3 & 2.34 & 2.37 & 2.36 & 0.01 \\
\hline CPI Japan & 19 & -0.01 & 0.02 & 0.01 & 0.01 \\
\hline BTC Price $€$ & 19 & 3.70 & $42,946.40$ & 589,759 & $10,756.14$ \\
\hline BTC Price \$ & 19 & 4.90 & $51,752.40$ & 700,921 & $12,992.57$ \\
\hline Fed Interest & 19 & 0.00 & 0.03 & 0.01 & 0.01 \\
\hline ECB Interest & 19 & 0.00 & 0.01 & 0.00 & 0.00 \\
\hline BOE Interest & 19 & 0.00 & 0.01 & 0.00 & 0.00 \\
\hline BOJ Interest & 19 & 0.00 & 0.00 & 0.00 & 0.00 \\
\hline Gold Futures & 19 & 1121.00 & 1895.19 & 1443.93 & 210.15 \\
\hline
\end{tabular}




\section{References}

1. Lacalle, D. La Gran Trampa: Por Qué los Bancos Centrales Están Abonando el Terreno Para la Próxima Crisis; Deusto: Barcelona, Spain, 2017.

2. Bagus, P. The Tragedy of the Euro; Ludwig von Mises Institute: Auburn, AL, USA, 2012.

3. de Soto, J.H. En defensa del euro: Un enfoque austríaco. Procesos Merc. Rev. Eur. Econ. Política 2012, 9, 15-49.

4. de Soto, J.H. Money, Bank Credit and Economic Cycles; Unión Editorial: Madrid, Spain, 2012.

5. Alonso, M.A.; Bagus, P.; Rallo, J.R. La crisis subprime a la luz de la teoría austriaca del ciclo económico: Expansión crediticia, errores de decisión y riesgo moral. Rev. Econ. Mund. 2010.

6. Mises, L.V. Human Action: A Treatise on Economics; Ludwig von Mises Institute: Auburn, AL, USA, 2007 ; p. 550.

7. Krugman, P.R. ¡Acabad ya Con Esta Crisis! Grupo Planeta (GBS): Madrid, Spain, 2012.

8. Ferguson, C. Inside Job: La Crisis Financiera se Llevó por Delante los Ahorros, los Empleos y los Sueños de Millones de Personas. Esto es lo que Ocurrió. Y estos Son los Culpables; Grupo Planeta Spain: Madrid, Spain, 2012.

9. Rallo, J.R. Crónicas de la Gran Recesión (2007-2009); Unión Editorial: Madrid, Spain, 2011.

10. Bagus, P.; Howden, D. The Federal Reserve and Eurosystem's Balance Sheet Policies during the Subprime Crisis: A Comparative Analysis. Rom. Econ. Bus. Rev. 2009, 4.

11. Guerini, M.; Lamperti, F.; Mazzocchetti, A. Unconventional Monetary Policy: Between the Past and Future of Monetary Economics. Ssrn Electron. J. 2018. [CrossRef]

12. de Soto, J.H. La japonización de la Unión Europea. Procesos Merc. Rev. Eur. Econ. Política 2019, 16, 317-342.

13. Rogoff, K. Monetary policy in a low interest rate world. J. Policy Model. 2017, 39, 673-679. [CrossRef]

14. Bagus, P. The ZIRP trap-The institutionalization of negative real interest rates. Procesos De Merc. Rev. Eur. Econ. Politica 2021, 12, 105-163. [CrossRef]

15. De Aguirre, J.A.; Castañeda, J.E. Una Crisis Económica Sorprendente (2007-2012); Ediciones Aosta: Madrid, Spain, 2012.

16. Bagus, P. Asset prices-An Austrian Perspective. Procesos De Merc. Rev. Eur. Econ. Política 2021, 4, 57-93. [CrossRef]

17. Ammous, S. El patrón Bitcoin: La Alternativa Descentralizada a los Bancos Centrales; Deusto: Barcelona, Spain, 2018.

18. Cachanosky, N.M. Does Bitcoin Have the Right Monetary Rule? SSRN Electron. J. 2018. [CrossRef]

19. Alonso, S.L.N. Activities and Operations with Cryptocurrencies and Their Taxation Implications: The Spanish Case. Laws 2019, 8, 16. [CrossRef]

20. Bas, D.S. Hayek and the cryptocurrency revolution. Iber. J. Hist. Econ. Thought 2020, 7, 15-28. [CrossRef]

21. Hayek, F.A. Denationalisation of Money: The Argument Refined: An Analysis of the Theory and Practice of Concurrent Currencies; Institute of Economic Affairs: London, UK, 1978.

22. Meynkhard, A. Energy efficient development model for regions of the Russian Federation: Evidence of crypto mining. Int. J. Energy Econ. Policy 2019, 9, 16-21. [CrossRef]

23. Giungato, P.; Rana, R.; Tarabella, A.; Tricase, C. Current Trends in Sustainability of Bitcoins and Related Blockchain Technology. Sustainability 2017, 9, 2214. [CrossRef]

24. Fadeyi, O.; Krejcar, O.; Maresova, P.; Kuca, K.; Brida, P.; Selamat, A. Opinions on Sustainability of Smart Cities in the Context of Energy Challenges Posed by Cryptocurrency Mining. Sustainability 2020, 12, 169. [CrossRef]

25. Samuelson, P.A. Economics; McGraw-Hill Companies: New York, NY, USA, 1970; p. 700.

26. Garrison, R. The Costs of a Gold Standard. The Gold Standard: An Austrian Perspective; Ludwig von Mises Institute: Auburn, AL, USA, 2014.

27. de Soto, J.H. Ensayos de Economía Política; Unión Editorial: Madrid, Spain, 2014.

28. Barrdear, J.; Kumhof, M. The Macroeconomics of Central Bank Issued Digital Currencies. Ssrn Electron. J. 2016. [CrossRef]

29. Sveriges Riksbank. The Riksbank's e-Krona Project; Report 2; Sveriges Riksbank: Stockholm, Sweden, 2018.

30. Griffoli, M.T.; Peria, M.M.; Agur, M.I.; Ari, M.A.; Kiff, M.J.; Popescu, M.A.; Rochon, M.C. Casting Light on Central Bank Digital Currencies; E-Book; International Monetary Fund: Washington, DC, USA, 2018.

31. Mayer, T. A Digital Euro to Compete with Libra. Econ. Voice 2019, 16. [CrossRef]

32. Echarte, M.A.; Sanz, D.; Nañez, S. Ventajas e Inconvenientes de las Divisas Virtuales Centralizadas (CBDC): Un Análisis de la Propuesta del Euro Digital; Libro de Actas del XIII Congreso de Economía Austríaca; Instituto Juan de Mariana: Madrid, Spain, 2020.

33. Auer, R.; Cornelli, G.; Frost, J. Rise of the Central Bank Digital Currencies: Drivers, Approaches and Technologies. BIS Working Papers NO. 880. 2020. Available online: https:/ / www.econstor.eu/handle/10419/229473 (accessed on 1 April 2021).

34. Nañez, A.; Echarte, M.A.; Sanz, D. Reasons Fostering or Discouraging the Implementation of Central Bank-Backed Digital Currency: A Review. Economies 2020, 8, 41. [CrossRef]

35. Ayuso, J.; Conesa, J.C. Una introducción al debate actual sobre la moneda digital de banco central (CBDC) (An Introduction to the Current Debate on Central Bank Digital Currency (CBDC)). SSRN Electron. J. 2020. [CrossRef]

36. Alonso, S.N.; Jorge-Vazquez, J.; Forradellas, R.R. Central Banks Digital Currency: Detection of Optimal Countries for the Implementation of a CBDC and the Implication for Payment Industry Open Innovation. J. Open Innov. Technol. Mark. Complex. 2021, 7, 72. [CrossRef]

37. Fabris, N. Cashless Society-The Future or Money or a Utopia? J. Cent. Bank. Theory Pract. 2019, 8, 53-66. [CrossRef]

38. Wu, J.C.; Xia, F.D. Negative interest rate policy and the yield curve. J. Appl. Econ. 2020, 35, 653-672. [CrossRef]

39. Castelnuovo, E. Yield Curve and Financial Uncertainty: Evidence Based on US Data. SSRN Electron. J. 2019. [CrossRef] 
40. Fornaro, L.; Wolf, M. Covid-19 Coronavirus and Macroeconomic Policy. CEPR Discussion Paper No. DP14529. 2020. Available online: https:/ / ssrn.com/abstract=3560337 (accessed on 24 March 2021).

41. Stock, J. Covid Economics: Vetted and Real-Time Papers; CEPR Press: Boca Raton, FL, USA, 2020.

42. Levin, A. Limitations on the Effectiveness of Monetary Policy Forward Guidance in the CONTEXT of the COVID-19 Pandemic; National Bureau of Economic Research: Cambridge, MA, USA, 2020.

43. Fondo Monetario Internacional. Actualización de las Perspectivas de la Economía Mundial; Fondo Monetario Internacional: Washington, DC, USA, 2020.

44. Albert, J.F.; Tercero-Lucas, D. Política monetaria en tiempos de pandemia: Evaluación y propuesta de Helicóptero Monetario. Rev. De Econ. Mund. 2020, 56. [CrossRef]

45. Ahmed, H.A. Monetary base and federal government debt in the long-run: A non-linear analysis. Bull. Econ. Res. 2020, 72, 167-184. [CrossRef]

46. Ibujés, S.; Orlando, M. Coeficiente de Correlación de Karl Pearson. Repositorio Digital Universidad Técnica del Norte Website. 9 December 2011. Available online: http:/ / repositorio.utn.edu.ec/handle/123456789/766 (accessed on 2 February 2021).

47. Ibujés, S.; Orlando, M. Probabilidades y Estadística Empleando las TIC. Repositorio Digital Universidad Técnica del Norte website. 13 June 2018. Available online: http:/ / repositorio.utn.edu.ec/handle/123456789/8698 (accessed on 3 February 2021).

48. Sampieri, R.H. Metodología de la Investigación: Las Rutas Cuantitativa, Cualitativa y Mixta; McGraw Hill México: Coyoacán, México, 2018.

49. Bagus, P.; Schiml, M.H. A Cardiograph of the Dollar's Quality: Qualitative Easing and the Federal Reserve Balance Sheet During the Subprime Crisis. Prague Econ. Pap. 2010, 19, 195-217. [CrossRef]

50. European Central Bank. Monetary Policy Decisions. European Central Bank. 2020. Available online: https:/ /www.ecb.europa.eu/ mopo/decisions/html/index.es.html (accessed on 25 March 2021).

51. Xing, Y. Japan's Practice of Modern Monetary Theory amid the Pandemic Recession. East Asian Policy 2020, 12, 47-56. [CrossRef]

52. Okano, E.; Eguchi, M. The importance of default risk awareness in conducting monetary and fiscal policies. Eurasian Econ. Rev. 2020, 10, 361-392. [CrossRef]

53. Bagus, P.; Howden, D. Central Bank Insolvency: Causes, Effects, and Remedies. J. Soc. Political Econ. Stud. 2015, 39, 3-23.

54. Bagus, P.; Peña-Ramos, J.; Sánchez-Bayón, A. COVID-19 and the Political Economy of Mass Hysteria. Int. J. Environ. Res. Public Heal. 2021, 18, 1376. [CrossRef]

55. Wray, L.R. Teoría Monetaria Moderna: MANUAL de Macroeconomía SOBRE los Sistemas Monetarios Soberanos; Lola Books: Madrid, Spain, 2015.

56. Rallo, J.R. Contra la Teoría Monetaria Moderna: Por qué Imprimir Dinero si Genera Inflación y por qué la Deuda Pública si la Pagan los Ciudadanos; Deusto: Barcelona, Spain, 2017.

57. Kelton, S. The Deficit Myth: Modern Monetary Theory and How to Build a Better Economy; Hachette: London, UK, 2020.

58. Alesina, A.; Favero, C.; Giavazzi, F. Austerity: When It Works and When It Doesn't; Princeton University Press: Princeton, NJ, USA, 2020.

59. Tercero-Lucas, D. Nonstandard monetary policies and bank profitability: The case of Spain. Int. J. Financ. Econ. 2021. [CrossRef]

60. Neal, L.; Cameron, R. A Concise Economic History of the World: From Paleolithic Times to the Present; Oxford University Press: New York, NY, USA, 2015.

61. Rodrik, D. The Globalization Paradox: Why Global Markets, States, and Democracy Can't Coexist; Oxford University Press: Oxford, UK, 2012.

62. Ravier, A.O. Dynamic Monetary Theory and the Phillips Curve with a Positive Slope. Ssrn Electron. J. 2012. [CrossRef]

63. Zafra, J.M.L. Retorno al Patrón oro: Por qué la Historia y la Actualidad lo Avalan Como la Solución Definitiva a la Crisis; Deusto: Barcelona, Spain, 2014.

64. Fernández, M.; Ángel, E.; Hernández, M.M.; Zambrano, O. Un análisis de la crisis económica de Venezuela desde los postulados de la Escuela Austríaca de Economía. Rev. Lasallista Investig. 2018, 15, 68-82. [CrossRef]

65. Kim, G. Why is China going to issue CBDC (Central Bank Digital Currency)? J. Internet Electron. Commer. Res. 2020, 20, 161-177. [CrossRef]

66. Paredes, P.L. La Dolarización: ¿Un Amor Eterno? Grupo Santillana: Quito, Ecuador, 2004.

67. Hinds, M. Playing Monopoly with the Devil: Dollarization and Domestic Currencies in Developing Countries; Yale University Press: London, UK, 2006.

68. Echarte, M.A. El impacto de la dolarización en América Latina. Procesos Merc. Rev. Eur. Econ. Política 2017, XII, 83-110.

69. Echarte, M.A. La Dolarización en América Latina: Un Análisis Desde la Perspectiva de la Escuela Austríaca; Unión Editorial: Madrid, Spain, 2019.

70. Libman, E. Política monetaria y cambiaria asimétrica en países latinoamericanos que usan metas de inflación. Rev. Cepal 2018, 2018, 29-46. [CrossRef]

71. Manrique, I. América Latina inflación sumergida. Probl. Del Desarro. 2015, 4. [CrossRef]

72. Ribeiro, J. Inflación de alimentos en Perú: El rol de la política monetaria. Rev. Análisis Económico 2019, 34, 81-98. [CrossRef]

73. European Central Bank. Report on a Digital Euro; European Central Bank: Frankfurt, Germany, 2020 ; pp. 10-22.

74. Náñez Alonso, S.L.; Jorge-Vazquez, J.; Reier Forradellas, R.F. Detection of Financial Inclusion Vulnerable Rural Areas through an Access to Cash Index: Solutions Based on the Pharmacy Network and a CBDC. Evidence Based on Ávila (Spain). Sustainability 2020, 12, 7480. [CrossRef] 